\title{
Family Status and Self-Motivation in Studies
}

\author{
Angel Mae Costaños \\ Department of Education Mandaue City Division \\ Mandaue City, Philippines \\ Tel: 63-928-570-2932Ｅ-mail: angelcostanos8@gmail.com \\ Jerald C. Moneva (Corresponding author) \\ Department of Education Mandaue City Division \\ Mandaue City, Philippines \\ Tel: 63-908-927-3038Ｅ-mail: freezingfire1979@gnail.com
}

\author{
Marsha H. Malbas (Corresponding author) \\ Mandaue City, Philippines \\ E-mail: marsha_m@yahoo.com
}

$\begin{array}{lc}\text { Received: February 13, } 2020 & \text { Accepted: March 19, } 2020 \quad \text { Published: March 21, } 2020 \\ \text { doi: } 10.5296 / \text { ire.v8i1.16456 } & \text { URL: https://doi.org/10.5296/ire.v8il.16456 }\end{array}$

\begin{abstract}
Family can inspire the child to perform well in school. When the students belong to a complete family they can gain more confidence to do the task. Students who have complete family can be encouraged themselves to produce positive learning style in their studies. When the student belongs to a broken family the set of behaviors can be different towards certain task. Using the correlation quantitative design, the study was conducted in the Jagobiao National High School-Senior High Department in which the data were treated with chi-square to determine the relationship between family status and self-motivation. As a result, family status and self-motivation has no significant correlation in studies of any students, self-motivation exist regardless of family status, broken and complete. The motivation of student deals with their innate behavior and attitude to achieve better academic performance.
\end{abstract}

Keywords: Academic performance, Family status, Self-motivation, Students and studies 


\section{Introduction}

\subsection{Rationale}

Family status refers to the characteristics of the family being rich, poor, broken and complete. The supporter of the finance is the family and they are the rule of the discipline towards the attitude of their children. Family is the one to guide their children to have a better future and better life. Family are the one who motivates for their children. On one hand, self-motivation is an activity that need to proceed without any hesitation. In fact, the students who have self-motivation can gain more confidence and positive thoughts. The children's motivation is their family because the family has a big responsibility to their children. The family being reflects the way children motivates themselves.

According to Suleman, Hussain, Akhtar and Khan (2012), family is the foundation and the supporter of their children whatever challenges it is, because family is the one who give hand to their children. The family is the one who motivate their children. Family motivates their children to study harder to have a bright future. However, there are certain families who have their own problem that badly affect's the student self-motivation in their academic performance for instance family problem. Students have a complicated family with a poor standard of life. But then, there are some children who not happy with their family because there are students who have complicated family resulting to student de-motivation. In fact, there are students also are not happy even their family is complete and less motivated because they need another piece to complete their own motivation. Family and students should have a strong relationship for education and support. According to Nematollahi, Tavakoli and Akbarzadeh (2017), puberty is very challenging stages of life of children because their whole body changes and cannot handle it by their own. This stages of life have many develop to happen like their motivation of themselves. Children who have less motivation can encounter academic problem.

The study aims to understand the relationship and association of family status and self-motivation. To point out if the researcher intended to reconcile the idea that family status either broken or complete motivation is something different and outside this scenario or rooted to this. It is important to understand more about self-motivation and the family status with complete or broken family, it is important to take note the student motivation whether "broken need" affected the motivation of the students. The study is only focusing on two variables since the study is bivariate.

\subsection{Theoretical Background}

The self-motivation is an activity that need to proceed without any hesitation. The self-determination theory (SDT) were created by the two theorist which is Richard M. Ryan and Edward L. Deci (2000). This explains the act of an individual for their motivation to succeed their goal. This theory observed the behavior of personality and the human motivation. Each one of us has our own motivation in life because we set a goal to finish that certain thing.

But, there is a sub theory was presented by Ryan and Deci (1985), which is cognitive evaluation theory. It focuses on social and environmental factors by the inner motivation and it uses language because it can be inheret or natured by own. The way of usage in language 
we used our expression because they see if you motivated something or others. On one hand, the SDT has also a second sub theory which is organismic integration (OIT) were presented also by Ryan and Deci (1985). It deals the outside motivation and the act of motivation as an individual. The outside motivation is needed to have a reward of their motivation. The OIT explains the process of an organism in the external.

Moreover, the SDT has a big role of this study of family status and self-motivation to support of this study. To discuss further, the self-motivation is something that motivated by yourself. Students have their own motivation that need to be succeed by their goal. The self-motivation have many aspects in motivating of one's self. It depends by their behavior and personality in motivating of a students. Eventually, this theory explains that student's motivation and family status are connected and how they approach as an individual. Ryan and Deci (2000) the nature of motivation is come from a person consistent to become more motivated. SDT (Self-Determination Theory) only concerned in positive development of a person on how it cope with social environments. The self-determination theory focuses on how the person applying it to themselves so that it can make them encourage to done their task.

To discuss further, self-motivation can be a product of several factors: family, students, environment and friends. Family Background is the basis of self-motivation of the students. The self-motivation of a student depends on their personality and behavior on how confidence they are. The theory of SDT is connected to this study because it supports the motivation of students and the role of a family to motivate their child. Ryan and Deci (2000) positive motivation have two choices either intrinsic and extrinsic motivation can enhance the performance of a student toward academic performance or achievement in life.

\subsection{Statement of Purpose}

The study intended to assess the association of family status either broken family or complete family, level of self-motivation and the significant relationship between family status and self-motivation in studies of Senior High students in Jagobiao National High School.

\subsection{Review of Related Literature}

This chapter presents the related literature and studies of researcher. This will also present the literature of each author to support the study/ to explain briefly the related and supporting studies.

\subsubsection{Family Status}

Mekennon (2017) said that the educational background of family has no specific impact on student academic achievement. Rabo (2018) stated that the parents who have higher educational attainment and good job are more on exposing their children on positive encouragement tend to get better academic performance than the children who did not receive positive encouragement. Egunsola and Isani (2015) said that whether the fanily type, size and marital status can affect on student academic performance; marital status and family size have a big relationship on students' achievement in school; over all parents must provide a productive home environmental to student on developing the educational performance in school. Ogbugo-Ololube (2016) indicated that the students' who have middle and high level of family background tend to pursue more on academic performance than the students'who have low family background have low performance in school. 
Nweke, Iherijika and Deebom (2018) said that family background of a student has a great impact or influence om academic achievement in primary schools. Osuafor and Okonkwo (2013) found that the family structure, parental occupation and parental education level have no significant impact on students' achievement in aubject in biology but the parents are more aware in giving attention on their children on their studies.

Olaitan (2017) mentioned that the significant difference of academic performance towards single parent and two parent families; two parent families pay more attention to their children while the single parent families suffer from negative attention to children. Amadi and Segun (2018) stated that the study observed the social status of families and academic performance of students in the way that parents give more encouragement to their children.

Marcen, Gimeno, Gómez, Sáenz and Gutiérrez (2013) mentioned that parental support association, socioeconomic and single parent family explained their involvement of the children activities in sport but the study result that there is no association between parental support and athlete income or the job status of family. Whitaker, Severtson, Furr-Holden and Latimer (2013) found that family functioning has an effect of neighborhood towards youth motivation in learning because of the environment surround.

Firmansyah (2014) said that parents need to motivate the children attitude towards saving money in the way the children know the value of money in their life.

\subsubsection{Self-motivation}

Sharma and Sharma (2018) mentioned that it does not matter whether a student is motivated or unmotivated or the student is. more motivated even if it is their late chilhood days. Student must not be affected the classroom environment and the teaching style used by teachers and need to enrich the intrinsic motivation of late childhood student.

Kalaivani and Rajeswari (2016) indicated that the students need to establish positive learning on academic achievement and dealing with behavioral problems of students so that teachers must demonstrate or show the effective strategies in enhancing and motivating. Kussainov, Boulatbayeva and Shaumen (2014) stated that in the school is the starting point of many opportunities of student; grade 8 and 9 must be active in motivating themselves as well as the high school students and aware in their future career.

Haider, Qureshi, Pirzada and Shahzadi (2015) indicated that extrinsic motivation has a lesser positive influence on academic performance than the intrinsic motivation otherwise students who use intrinsic motivation is more skillful. Husain (2014) mentioned that self-efficacy is the one who predict the students' motivation and learning but the study of this did not confirm that there is a significant difference between academic motivation and self-efficacy. Emmanuel, Adom, Josephine and Solomon (2014) found that all the high school students are more motivated, high in self-concept and they performed well on their mathematics achievement test and enhance or improve their performance.

Zoabi (2012) stated that nature of association between self-image and motivation on regular students and there are many opportunities in choosing courses of high school student in academics.

Hassan and Thava (2017) indicated that students in Kuala Langat, Selangor found out intrinsic and extrinsic motivation has a great impact on academic achievement to enhance 
their motivation level. Ubale, Abdurrahman and Abdullah (2015) stated that intrinsic motivation technique is very useful un positive way in dealing the studies of students and parents are the one to guide their children to get a positive outcome.

Adamma, Ekwutosim and Unamba (2018) found that self-efficacy is very important in enhancing the academics of students' who while the male students are paying their attention in enhancing. Remali, Ghazali, Kamaruddin and Kee (2013) mentioned that the intrinsic motivation is useful in coping stress exam and it has a good impact on student performance. Saeed and Syngier (2012) indicated that motivation and engagement are the some of the factors in guiding behavior of teachers can relate their learning style.

Solak (2012) said that motivational factors affect the academic achievement of English as a Foreign Learners and gender role of academics that can develop in different academic major. Gbollie and Keamu (2017) said that liberian junior and senior high have various strategies in learning and different motivational beliefs in a way to increase their academic performance.

Rani and Reddy (2019) found that the academic achievement motivation is the one to predict the future success. In order to achieve the success in academics, teachers need to reduce the gender difference in achieving academic.

Self-motivation is to know whether there is a difference between self-motivation of children with broken and children with complete family. Most of the studies established the role parents in childrens motivators. However, motivation is worth to be assessed whether it affect the children.

\section{Research Method}

\subsection{Design}

The study used correlational quantitative design because it explores the relationship between variables by using statistical analysis. It involves analyzing, recording, computing and interpreting the two variables of family status and self-motivation.

\subsection{Environment}

The study was conducted in Jagobiao National High School in Senior High Department. The Jagobiao National High School is located at the Upper Jagobiao Rd, Mandanue City, Cebu.

The Senior High Department have a two buildings that used by the senior high students. The first building of Senior High Department have a third floor; the first floor is occupied by the faculty teachers of senior high and the computer laboratory, the second floor is occupied by the grade 11 students which is HUMSS and TVL, the third floor is occupied also by the Grade 11 students of ABM and GAS.

The new building of Senior High Department have a fourth-storey building; the first floor is occupied by the Grade 12 ABM and Grade 7 students and room for the cookery students; the second floor is occupied by the Grade 12 GAS and HUMSS; the third floor is occupied by the Grade 11 STEM; and the fourth floor is vacant.

\subsection{Respondents}

The respondents of this study are the Grade 11 and students of Jagobiao National High School in Senior High Department which is the GAS, ABM, HUMSS, STEM and TVL. The GAS-11 has 36 students; ABM-11 has a 23 students; HUMSS-11 have a 41 students; for the 
STEM-11 have a 32 students; and the TVL-11 have a 7 students, and also the Grade 12 students which is the GAS, ABM, HUMSS. The GAS 12 has 21 students; ABM have 25 students; and the HUMSS have 41 students. The study focused only among the students in Senior High School of Jagobiao National High School. The sampling data gathered in Jagobiao National High School. The results showed that 154 students are complete family while 72 students are broken family. The total respondents are 226 in all.

\subsection{Instruments}

The type of instrument used by the researcher in the study of family status and self-motivation was the survey questionnaire. The first part of the questionnaire is the family status of the respondents. The second part is the positive self-motivation of the respondents. This questionnaire is adopted from the site of Think Impact Solutions. The questionnaire has 12 indicators for the self-motivation, while the family status has only 2 indicators either broken or complete family. The 12 indicators of self-motivation rate from 1 to 5: 1- very rarely, 2- seldom, 3- sometimes, 4- usually and 5- very often. Then, add the score of the respondents and the highest possible score is 60 .

\subsection{Data Gathering and Procedure}

Before the researcher gathers the data the researcher need to make a transmittal letter to be signed and approved by the principal, the teacher of practical research 2 and the researcher. After, approved the transmittal letter the researchers directly go to administers to the survey questionnaire. The survey questionnaire distributed to the respondents personally. Then, the researcher give instructions and guide the respondents about the survey questionnaire. The researcher collected the answers of the respondents and it is the basis of the researcher in interpreting, analyze, findings, conclusion and recommendation of this study.

\subsection{Instrument}

The type of instrument used by the researcher in the study of family status and self-motivation was the survey questionnaire. The first part of the questionnaire is the family status of the respondents. The second part is the positive self-motivation of the respondents. This questionnaire is adopted from the site of Think Impact Solutions. The questionnaire has 12 indicators for the self-motivation, while the family status has only 2 indicators either broken or complete family. The 12 indicators of self-motivation rate from 1 to 5: 1- very rarely, 2- seldom, 3- sometimes, 4- usually and 5- very often. Then, add the score of the respondents and the highest possible score is 60 . 


\section{Data Analysis and Discussion}

Table 1. Complete Family: Level of Self-Motivation

\begin{tabular}{lll}
\hline Indicators & WM & Interpretation \\
\hline 1. I'm confident in my ability to achieve goals I set for myself. & 3.47 & Usually \\
2. When working on my goals, I put forth my best. & 3.57 & Usually
\end{tabular}

3. I set written goals and objectives on an annual basis to achieve what I aspire for in life.

3.30 Sometimes

4. I think positively about setting goals and working towards achieving them.

$3.41 \quad$ Usually

5. I reward myself when accomplishing significant goals.

$3.36 \quad$ Sometimes

6. I believe that if I work hard and apply my abilities and talents, I will be successful.

3.68 Usually

7. I am aware of my deadlines and ensure I meet or exceed them.

3.47 Usually

8. When an unexpected situation jeopardizes me from accomplishing a goal, I consider my options and work diligently towards still achieving it.

\subsection{Sometimes}

9. My biggest reward after completing something is the satisfaction of knowing I've done a good job.

\subsection{Sometimes}

10. I tend to put forth my best effort so that I feel proud of my work.

\subsection{Usually}

11. I set challenging goals for myself.

$3.37 \quad$ Sometimes

12. Before I embark on a new substantial goal, I clearly understand what is involved in the process, how long it will take to accomplish, and how it aligns with what is the most important to me in my life.

$\begin{array}{ll}3.48 & \text { Usually } \\ 3.47 & \text { Usually }\end{array}$

$\mathrm{N}=154$ Legend: 1.00-1.80=Very Rarely, 1.81-2.60=Seldom, 2.61-3.40=Sometimes, 3.41-4.20=Usually, 4.21-5.00=Very Often

ThinkImpactSolutions(2010).https://kellyholloway.weebly.com/uploads/1/1/7/0/11708533/self motivation_assessment_tool.pdf

In the Table 1 shows that the overall calculated weighted mean of the complete family and level of self-motivation has 3.47 out of 12 indicators and interpreted as usually. The table signifies that students are usually motivated in doing their task in any activities in school. Nematollahi, Tavakoli and Akbazzadeh (2017) said that self-esteem and academic achievement can be structured as good or bad because of daily task. Zoabi (2012) found that students who are prepare in their studies are more motivated same as regular students. 
Table 2. Broken Family: Level of Self-Motivation

Indicators
1. I'm confident in my ability to achieve goals I set for myself.
2. When working on my goals, I put forth my best.
3. I set written goals and objectives on an annual basis to achieve
what I aspire for in life.

WM

Interpretation

4. I think positively about setting goals and working towards achieving them.

$3.38 \quad$ Sometimes

$3.33 \quad$ Sometimes

5. I reward myself when accomplishing significant goals.

3.53 Usually

6. I believe that if I work hard and apply my abilities and talents, I will be successful.

\subsection{Sometimes}

7. I am aware of my deadlines and ensure I meet or exceed them.

$3.11 \quad$ Sometimes

8. When an unexpected situation jeopardizes me from accomplishing a goal, I consider my options and work diligently towards still achieving it.

\subsection{Sometimes}

9. My biggest reward after completing something is the satisfaction of knowing I've done a good job.

3.47 Usually

10. I tend to put forth my best effort so that I feel proud of my work.

$3.49 \quad$ Usually

11. I set challenging goals for myself.

3.39 Sometimes

12. Before I embark on a new substantial goal, I clearly understand what is involved in the process, how long it will take to accomplish, and how it aligns with what is the most important to me in my life.

3.15 Sometimes

\begin{tabular}{lll}
\hline Overall Weighted Mean & 3.37 & Usually \\
\hline
\end{tabular}

$\mathrm{N}=72$ Legend: 1.00-1.80=Very Rarely, 1.81-2.60=Seldom, 2.61-3.40=Sometimes, 3.41-4.20=Usually, 4.21-5.00=Very Often

ThinkImpactSolutions(2010).https://kellyholloway.weebly.com/uploads/1/1/7/0/11708533/self motivation_assessment_tool.pdf

In the Table 3 shows that the overall calculated weighted mean of the broken family and level of self-motivation has 3.37 out of 12 indicators and interpreted as sometimes. The table signifies that students are usually motivated in doing task in school. Remali, Ghazali, Kamaruddin and Kee (2013) said that student can decide their path in future and it can result a positive attitude of motivation. Osuafor and Okonkwo (2013) stated that family status and family structure has no influence to student academic due to parent can distinguish the best for their child. 
Table 3: Family Status *Broken*Complete*

\begin{tabular}{llllll}
\hline & & Frequency & Percent & Valid Percent & Cumulative Percent \\
\hline Valid & Complete & 154 & 68.1 & 68.1 & 68.1 \\
& Broken & 72 & 31.9 & 31.9 & 100.0 \\
& Total & 226 & 100.0 & 100.0 & \\
\hline Total & & 251 & 100.0 & & \\
\hline
\end{tabular}

The table reveals the frequency of the student family status that 154 students have complete family and 72 students have broken family. The study of Ratelle, Guay, Larose and Senécal (2004) indicated that parent involvement of students is better to get away the negative impact of changing environment in school. Haider, Qureshi, Pirzada and Shahzadi (2015) stated that students are intrinsically motivated are the better in academic achievement than students extrinsically motivated.

Table 4. Level of Self-Motivation

\begin{tabular}{lllll}
\hline & Frequency & Percent & Valid Percent & Cumulative Percent \\
\hline slightly motivated & 3 & 1.2 & 1.3 & 1.3 \\
fairly motivated & 16 & 6.4 & 7.1 & 8.4 \\
moderately motivated & 97 & 38.6 & 42.9 & 51.3 \\
well-motivated & 76 & 30.3 & 33.6 & 85.0 \\
highly motivated & 34 & 13.5 & 15.0 & 100.0 \\
Total & 226 & 90.0 & 100.0 & \\
\hline Total 226 & & 100.0 &
\end{tabular}

The table reveals the frequency of the student self-motivation and it showed that 97 out of 226 are moderately motivated in studies. The table signifies a positive motivation of students in their studies. It pointed out that the sample are valid and reliable. Adamma, Ekwutosim and Unamba (2018) said that teachers need to learn how to engage their students in better learning in mathematics in that way they know the meaning of learning. Rani and Reddy (2019) found that student must exposed in positive self-concept and self-esteem to develop their learning in academic performance in school 
Table 5. Family Status and Self-Motivation Crosstabulation

\begin{tabular}{|c|c|c|c|c|c|c|}
\hline & & Self-Motiv & tion & & & \\
\hline & $\begin{array}{l}\text { slightly } \\
\text { motivated }\end{array}$ & $\begin{array}{l}\text { fairly } \\
\text { motivated }\end{array}$ & $\begin{array}{l}\text { moderately } \\
\text { motivated }\end{array}$ & $\begin{array}{l}\text { well- } \\
\text { motivated }\end{array}$ & $\begin{array}{l}\text { highly } \\
\text { motivated }\end{array}$ & Total \\
\hline Family complete & 1 & 9 & 69 & 52 & 23 & 154 \\
\hline Status broken & 2 & 7 & 28 & 24 & 11 & 72 \\
\hline Total & 3 & 16 & 97 & 76 & 34 & 226 \\
\hline
\end{tabular}

When the data cross tabulated the family status and self-motivation of the respondents. Most of the students are moderately motivated in their studies. The data gathered can be more idealistic and it can create deeper meaning of the two variables that influenced the students motivation either broken or complete family. Shute, Hansen, Underwood and Razzouk (2011) expressed that parents play a special role in influencing their children on academics by giving time to talk each other, giving expectations to the child and the way the parents handle on it.

Table 6. Chi-Square of Independence

\begin{tabular}{llll}
\hline & Value & df & Asymp. Sig. (2-sided) \\
\hline Pearson Chi-Square & $3.123^{\mathrm{a}}$ & 4 & .537 \\
Linear-by-Linear Association & .394 & 1 & .530 \\
\hline N of Valid Cases & 226 & & \\
\hline
\end{tabular}

a. 2 cells $(20.0 \%)$ have expected count less than 5 . The minimum expected count is .96 .

The study reveals that there is no significant relationship between two variables of family status and self-motivation in studies because the $\mathrm{p}$ value is greater than the alpha. The correlation is not significant at the .537 level ( 2 sided $)$ and $(p=.00>.05)$.

Similarly, Kussainov, Boulatbayeva and Shaumen (2014) found that there is no significant effect on students progression on academics in school because of the quality of education and developed knowledge. Zoabi (2012) said that the self-esteem has no significant correlation with motivation for learning of students in preparatory program. Osuafor and Okonkwo (2013) found that family background, family structure, parental occupation and parental education has no significant has no significant impact on student achievement in school.

\section{Findings}

The students family status and their level of self-motivation showed an usually interest in studying. Most of the students want to achieve better performance in school.

There is no significant correlation between family status and self-motivation in studies. Self-motivation of a student has no basis in studying even their status in family is broken or 
complete. Students have own self-motivation for their studies.

\section{Conclusion}

Students who come from different types of family background either broken family or complete family have no better academic performance in school because the result is not significant of the two variables. Self-motivation of student shown most of the respondents has average score. It found that the students agreed that they are more motivated for their own whether their family is broken or complete family. Students motivation can get a high academic performance; students unmotivated cannot get also high academic performance. In other words, the word motivation only come from the student because the student can decide whether he/she is motivated more or unmotivated in studies.

Self-determination theory encompasses the personality and human motivation. Students are motivated regardless of family status whether complete family and broken family. In which in this study, students are self motivated to achieve positive development and get better performance in school. On the study of Khajehpour and Ghazvini (2011) found that parental involvement has big purpose on educating their children to improve the performance as the main educator. Chohan and Khan (2010) stated that parental support build a child to have positive self-image and better foundation of performance and develop being matured. But this is not always the case, the study of Rosnati, Barni and Uglia (2014) said that youths come from separated/divorced families are need to prioritize to have a happy goal in life.

\section{Recommendation}

Based on the findings of this research study, the students cannot identify on how to motivate themselves even if they encounter different circumstances in achieving good academic performance in Jagobiao National High School. The students are still in improving their learning in school because students do not know how to cope on it. Parents play a vital role in enhancing, improving and guiding to their child to have a better future. Students did not influence whether the family are broken or complete. Also, the student has a role in motivating themselves because the only way to motivate is from their innate self. Students should motivate themselves to have achieved in motivating in studying.

\section{Acknolowdgement}

I would like to acknowledge our school principal, Mrs. Juvy M. Sosas for the completion of my study. I would also like to acknowledge Ms. Flory Joy V. Cabase and Ms. Wendelyn T. Bacante for helping me throughout my study and lastly, I would like to thank to my family for supporting my financial needs in conducting this study.

\section{References}

Abbas, M., \& Khurshid, F. (2013). Motivational techniques and learners academic achievement at primary level. Global Journal of Human Social Science, 13(3), 1.

Adamma, O. N., Ekwutosim, O. P., \& Unamba, E. C. (2018). Influence of extrinsic and intrinsic motivation on pupils academic performance in mathematics. (Supremum Journal of Mathematics Education), 2(2), 5259.

Amadi, E. C., \& Segun, I. (2018). The influence of family social status on academic performance of senior secondary students: a review. (International Journal of innovative Social \& Science Education Research), 6(1), 2529. 
Azar, F. S. (2013). Self-efficacy, achievement motivation and academic procrastination as predictors of academic achievement in pre-college students. Proceeding of the Global Summit on Education.

Chohan, B. I., \& Khan, R. M. (2010). Impact of parental support on the academic performance and self concept of the student. Journal of Research and Reflections in Education, 4(1), 14-26.

Egunsola, A. O. E., \& Isani, A. C. (2015). Influence of parental marital status, family type and size on academic performance of secondary school students in agricultural science in adamawa state nigeria. Journal of education Research and Behavioral Sciences, 4(4), 142-147.

Emmanuel, A. O., Josephine, B., Solomon, F. K., \& Adom, E. A. (2014). Achievement motivation, academic self-concept and academic achievement among high school students. European Journal of Research And Reflection in Educational Sciences, 2(2).

Firmansyah, D. (2014). The influence of family backgrounds towards students' saving behavior: a survey of college students in jabodetabek. International Journal of Scientific and Research Publications, 41. https://doi.org/10.2139/ssrn.2358346

Gbollie, C., \& Keamu, H. P. (2017). Student Academic Performance: The Role of Motivation, Strategies, and Perceived Factors Hindering Liberian Junior and Senior High School Students Learning. Education Research International, 11. https://doi.org/10.1155/2017/1789084

Haider, S. A., Qureshi, M. M., Pirzada, S. S., \& Shahzadi, I. (2015). A study of student's motivation and its relationship with their academic performance. Journal of Resources Development and Management, 8.

Hassan, N. C., \& Thava, M. (2017). Motivation and academic achievement: a case study of malaysian aboriginal (orang asli) students. International Journal of Academic Research in Business and Social Sciences, 4(7). https://doi.org/10.6007/IJARBSS/v7-i14/3687

Hussain, U. K. (2014). Relationship between self-efficacy and academic motivation. International Conference on Economics, Education and Humanities.

Kalaivani, M., \& Rajeswari, V. (2016). The role of academic motivations and academic self-concept in students's academic achievement. International Journal of Research-Granthaalayah, 9(4).

Kussainov, A. K., Boulatbayeva, A. A., \& Shaumen, G. S. (2014). Family situation as factor of the academic progress of students. International Journal of Humanities and Social Science, 14(4).

Khajehpour, M., \& Ghazvini, S. D. (2011). The role of parental involvement affect in children's academic performance. Procedia Social and Behavioral Sciences, 15, 1204-1208. https://doi.org/10.1016/j.sbspro.2011.03.263

Marcen, C., Gimeno, F., Gómez, C., Sáenz, A., \& Gutiérrez, H. (2013). Socioeconomic status, parental support, motivation and self-confidence in youth competitive sport. Procedia Social and Behavioral, 82, 750-754. https://doi.org/10.1016/j.sbspro.2013.06.342

Mekonnen, M. A. (2017). Effects of family educational background, dwelling and parenting style on students' academic achievement: The case of secondary schools in Bahir Dar. 
Educational Research and Reviews, 12(18), 939-949.

Nematollahi, A., Tavakoli, P., \& Akbarzadeh, M. (2017). The relationship between self-esteem and students' academic achievement and some parental demographic factors. Scholars Journal of Applied Medical Science, 5(5A), 1758-1764.

Nweke, D. C., Ihejirika, J. C., \& Deebom, Z. D. (2018). Influence of family background on academic achievement of pupils schools in port harcourt city local government area, rivers state. International Journal of Education and Evaluation, 3(4).

Ogbugo-Ololube, R. O. (2016). Impact of students' parental background on academic achievement in secondary schools in obio/akpor LGA, rivers state, nigeria. International Journal of Scientific Research In Education, 9(2), 115-126.

Olaitan, A. W. (2017). Impact of family structure on the academic performance of secondary school students in yewa local government area of ogun state, nigeria. International Journal of Sociology and Anthropolgy Research, 1(3), 1-10.

Osuafor, A., \& Okonkwo, I. (2013). Influence of family background on academic achievement of secondary school biology students in anambra state. An International Multidisciplinary Journal, Ethiopia, 7(3), 156-167. https://doi.org/10.4314/afrrev.v7i3.12

Rabo, M. U. (2018). An appraisal of parental background and students academic performance in nigeria. IOSR Journal of Research \& Method in Education, 6(8), 01-05.

Rani, P., \& Reddy, G. (2019). A study on achievement motivation of adolescents students of different academic streams.International Journal of Current Microbiology and Applied Sciences, 2(8). https://doi.org/10.20546/ijcmas.2019.802.028

Ratelle, C. F., Guay, F., Larose, S., \& Senecal, C. (2004). Family correlates of trajectories of academic motivation during a school transition: a semiparametric group- based approach. Journal of Educational Psychology, 96, 743-754. https://doi.org/10.1037/0022-0663.96.4.743

Remali, A. M., Ghazali, M. A, Kamaruddin, M. K., \& Kee, T. Y. (2013). Understanding academic performance based on demographic factors, motivation factors and learning styles. International Journal of Asian Social Science, 3(9), 1038-1951.

Rosnati, R., Barni, D., \& Uglia, D. (2014). Adolescents and parental separation or divorce: The protective role of values against transgressive behavior. Procedia-Social and Behavioral Sciences, 140, 186-191. https://doi.org/10.1016/j.sbspro.2014.04.407

Ryan, R. M., \& Deci, E. L. (2000). Self-determination theory and the facilitation of intrinsic motivation, social development, and well-being. American Psychologist Association, Inc. 55(1), 68-78. https://doi.org/10.1037/0003-066X.55.1.68

Saeed, S., \& Zyngier, D. (2012). How motivation influences student engagement: a qualitative case study. Journal of Education and Learning, 2(1). https://doi.org/10.5539/jel. v1n2p252

Solak, E. (2012). Exploring the role of motivation factors in the academic achievement of EFL learners. International Association of Research in Foreign Language Education and Applied Linguistics ELT Research Journal, 1(4), 240-254.

Suleman, Q., Hussain, I., Akhtar, Z., \& Khan, W. (2012). Effects of family structure on the academic achievement of students at elementary level in karak district, pakistan. Journal of 
Sociological Research, 2(3). https://doi.org/10.5296/jsr.v3i2.2358

Sharma, D., \& Sharma, S. (2018). Relationship between motivation and academic achievement. International Journal of Advances in Scientific Research, 4(1). https://doi.org/10.7439/ijasr.v4i1.4584

Shute, V. J., Hansen, E. G., Underwood, J. S., \& Razzouk, R. (2011). A rrview of the relationship between parental involvement and secondary school students' academic achievement. Education Research International. https://doi.org/10.1155/2011/915326

Ubale, A. Z., Abdurrahman, T., \& Abdullah, A. H. (2015). A relationship between parental involvement and intrinsic motivation on learning islamic education. Arts Social Sci J, 6, 115. https://doi.org/10.6007/IJARBSS/v5-i7/1744

Whitaker, D., Graham, C., Severtson, S. G., Furr-Holden, D. C., \& Latimer, W. (2012). Neighborhood \& family effects on learning motivation among urban african american middle school youth. J Child Fam Stud, 21(1), 131-138. https://doi.org/10.1007/s10826-011-9456-1

Zoabi, K. (2012). Self-esteem and motivation for learning among minority students: a comparison between students of pre-academic and regular programs. Creative Education, 8(3). https://doi.org/10.4236/ce.2012.38204

\section{Appendix I}

\section{Tool: Checklist}

Family Background:

Gender:

Age:

$\begin{array}{ll}\text { Broken Family } & \text { [ ] } \\ \text { Complete Family } & \text { [ ] }\end{array}$

Male [ ]

Female [ ]

Self- Motivation Assessment Tool

Instructions: This assessment tool is designed to enhance awareness of your level of self-motivation. For each statement below, mark a check in each box. Once completed, determine your total score and read the interpretation of your score, which includes ideas of ways to enhance your level of self-motivation. Answer it honestly.

LEGEND:

1- Very Rarely 2-Seldom 3-Sometimes 4- Usually 5-Very Often

\begin{tabular}{|c|c|c|c|c|c|c|}
\hline & & 1 & 2 & 3 & 4 & 5 \\
\hline 1 & I'm confident in my ability to achieve goals I set for myself. & & & & & \\
\hline 2 & $\begin{array}{l}\text { When working on my goals, I put forth my best effort and work even } \\
\text { harder if I've encountered a setback. }\end{array}$ & & & & & \\
\hline 3 & $\begin{array}{l}\text { I set written goals and objectives on an annual basis to achieve what I } \\
\text { aspire for in life. }\end{array}$ & & & & & \\
\hline 4 & $\begin{array}{l}\text { I think positively about setting goals and working towards achieving } \\
\text { them. }\end{array}$ & & & & & \\
\hline
\end{tabular}




\begin{tabular}{|c|c|}
\hline 5 & I reward myself when accomplishing significant goals. \\
\hline 6 & $\begin{array}{l}\text { I believe that if I work hard and apply my abilities and talents, I will be } \\
\text { successful. }\end{array}$ \\
\hline 7 & I am aware of my deadlines and ensure I meet or exceed them. \\
\hline 8 & $\begin{array}{l}\text { When an unexpected situation jeopardizes me from accomplishing a } \\
\text { goal, I consider my options and work diligently towards still achieving } \\
\text { it. }\end{array}$ \\
\hline 9 & $\begin{array}{l}\text { My biggest reward after completing something is the satisfaction of } \\
\text { knowing I've done a good job. }\end{array}$ \\
\hline 10 & I tend to put forth my best effort so that I feel proud of my work. \\
\hline 11 & I set challenging goals for myself. \\
\hline 12 & $\begin{array}{l}\text { Before I embark on a new substantial goal, I clearly understand what is } \\
\text { involved in the process, how long it will take to accomplish, and how it } \\
\text { aligns with what is important to me in my life. }\end{array}$ \\
\hline
\end{tabular}

References:ThinkImpactSolutions(2010).https://kellyholloway.weebly.com/uploads/1/1/7/0/11 708533/selfmotivation_assessment_tool.pdf

\section{Copyright Disclaimer}

Copyright reserved by the authors.

This article is an open-access article distributed under the terms and conditions of the Creative Commons Attribution license (http://creativecommons.org/licenses/by/3.0/). 